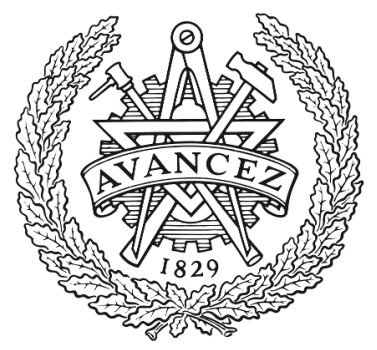

CHALMERS

UNIVERSITY OF TECHNOLOGY

\title{
Real Options in Management and Organizational Strategy: A Review of Decision-making and Performance Implications
}

Downloaded from: https://research.chalmers.se, 2023-04-26 08:39 UTC

Citation for the original published paper (version of record):

Driouchi, T., Bennett, D. (2012). Real Options in Management and Organizational Strategy: A

Review of Decision-making and

Performance Implications. International Journal of Management Reviews, 14(1): 39-62.

http://dx.doi.org/10.1111/j.1468-2370.2011.00304.x

N.B. When citing this work, cite the original published paper. 
Real Options in Management and Organisational Strategy-A Review of Decisionmaking and Performance Implications

\title{
Tarik Driouchi
}

Department of Management, King's College London, University of London, SE1 9NH, London, UK.

tarik.driouchi@kcl.ac.uk

\section{David J. Bennett}

International Graduate School of Business, University of South Australia, Adelaide SA5001, Australia; Aston Business School, Aston University, Birmingham B4 7ET, UK; Department of Technology Management and Economics, Chalmers University of Technology, 41296 Gothenburg, Sweden

\begin{abstract}
This paper contributes to the debate on the role of real options theory in business strategy and organisational decision-making. It analyses and critiques the decisionmaking and performance implications of real options within the management theories of the (multinational) firm, reviews and categorises the organisational, strategic and operational facets of real options management in large business settings. It also presents the views of scholars and practitioners regarding the incorporation and validity of real options in strategy, international management and business processes ${ }^{1}$. The focus is particularly on decision-making and performance attributes of the real options logic concerning strategic investments, governance modes and multinational operations management. These attributes are examined from both a strategic and operating perspective of decision-making in organisations, with also an overview of the empirical evidence on real options decision-making and performance.
\end{abstract}

\footnotetext{
${ }^{1}$ Research related to the theoretical features of real options models are disregarded from this survey; a broad coverage of quantitative contents can be found in Schwartz and Trigeorgis (2001).
} 


\section{Introduction}

The real options paradigm offers an especially relevant framework for decision-making under uncertainty in the study of organisations (e.g. Bowman and Moskowitz 2001; Sanchez 2003). It provides an alternative and dynamic view of the structural processes that define and frame company strategy towards achieving sustainable competitive advantage (Bowman and Hurry 1993; Smit and Trigeorgis 2007). This paradigm, which is also valid in small business settings ${ }^{2}$, has prompted considerable debate in the study of large and profit maximising organisations (Zardkoohi 2004). In theory, real options offer flexibility, resources and the capability to benefit from the uncertainty surrounding business, but it still remains to be seen whether firms are able to capitalise on such opportunities in practice. Specifically, (how) do managers recognise and exploit real options opportunities? (How) do real options influence managerial decision-making? Is the real options logic/technique really practiced in corporations? Do real options add (reduce) value (risk) and enhance firm competitive advantage?

To answer these questions we review the extant literature on real options theory in management and organisation strategy, examine the various perspectives (i.e. conceptual and empirical) on its decision-making and performance implications, and discuss opportunities and directions for future research in the area. We choose to emphasise the role of real options decision-making in strategic investments and multinational operations ${ }^{3}$ to explain the impact of real options, as flexibility platforms in multinational networks (e.g. expanding, switching, delaying, abandonment etc), on economic behaviour, performance and risk parameters (Kogut and Kulatilaka 1994a; Tong and Reuer 2007a).

Through recognition, structuring and analysis of real options configurations in projects and operating systems, managers can equip their organisations with the flexibility to mitigate their downside risk and enhance upside potential within asymmetric information and decision-making settings (i.e. through a combination of "wait-and-see" and partly reversible commitment). In this sense, embracing an option-based view of decision-making towards strategic planning and resources management can enable the exploration and exploitation of the flexibility embedded in systems and operations, develop real options decision-making as a systemic capability, and take advantage of uncertainty via adaptability, change and renewal. When viewed from a multinational business perspective, real options and real options decision-making ${ }^{4}$ address issues related to the design and analysis of strategic foreign investments, the choice of governance modes, and management of international operations. From a theoretical standpoint the concept of real options also offers robust explanations about existing perspectives of MNCs (e.g. multinational network hypothesis, internalisation and international diversification) (Rugman and Li 2005). Multinationality constitutes a source of real options and flexibility value not necessarily owned by domestic firms and is amplified by the heterogeneity of foreign markets, information incompleteness and growth opportunities in emerging economies (Kogut 1984, 1985). However, behavioural and infrastructural factors in decision-making can make such flexibility costly and complex for organisations to manage, so would discourage the exploitation

\footnotetext{
${ }^{2}$ See for example Hurry et al. (1992) and Li (2008).

${ }^{3}$ Mainly with respect to large corporations (MNCs).

${ }^{4}$ Real options decision-making is defined here as managers' ability to notice, maintain, champion and exploit real options opportunities in their business environments (see Barnett 2008).
} 
of real options opportunities in investments and operations (Reuer and Leiblein 2000; Barnett 2003; Adner and Levinthal 2004a). This argument questions the usefulness of what a number of commentators would view as a "luxurious" theory of managerial entrepreneurship and excessive flexibility. Several studies have been conducted to define, analyse/appraise, criticise and frame the real options concept in the management and organisational strategy literature (e.g. Garud et al. 1998; Adner and Levinthal 2004b; Barnett 2008; Krychowski and Quelin 2010). We contribute to this debate by providing a comprehensive survey of existing work on real options in management and decision-making research, presenting current evidence on the subject, and underlining how real options might influence managerial decision-making and contribute to corporate performance. We consider that the study of MNCs offers a suitable research landscape for the positioning of real options theory in the corporate strategy and multinational business domains, especially vis-à-vis firms' decision-making and performance attributes. Thus, the role of real options theory in organisations is clarified, its application to business strategy and international management critically examined, and empirical evidence on real options decision-making and performance is summarised. Other examples of literature surveys conducted in this area include the work on real R\&D options of Newton et al. (2004), on empirical real options research in corporate strategy by Reuer and Tong (2007a), and on international market entry and the value of multinational networks by Li (2007a).

The remainder of the review proceeds as follows. The next section discusses the various perspectives on real options decision-making in the general area of organisations and makes a distinction between the (explicit/implicit) use of real options as heuristics for strategy formulation, decision tools for project management and optimisation, and capabilities for organisational evolution and managerial decision-making. After this there is a section identifying the main themes linking (multinational) real options with theories of the firm and examines the potential and actual contribution of flexibility and uncertainty in the process of achieving competitive advantage. Then there are two final sections covering recent findings and empirical evidence on the validity of real options theory in strategy and multinational business research, emphasising its decision-making and performance implications, analysing methodologies employed and highlighting industry applications.

\section{Real Options Decision-Making}

Several publications consider the study of real options theory and its application to corporate strategy and organisations (Bowman and Hurry 1993; Barnett 2005; Lee et al. 2007; Tong and Reuer 2007b) and a useful debate has emerged that assesses the validity of such a view of decision-making in business strategy, performance and organisational management (Adner and Levinthal 2004a; McGrath et al. 2004). Proponents of this view stress the benefits for managerial flexibility and the value created from uncertainty when making strategic and operating decisions (Luehrman 1998a; McGrath 1999). Opponents highlight the dangers behind real options decisionmaking and management in firms (Coff and Laverty 2001; Carr 2002). Before presenting the details of this debate in later sections and positioning the concept of real options in strategy and multinational business, it is necessary to define the context of real options and real options decision-making in organisations. 
Real options decision-making represents the set of decisions used to trigger and assess flexibility, whether relying on real options valuation or real options reasoning or simply by being influenced by implicit real options effects (Trigeorgis 1999; O'Brien and Folta 2009). Assuming every firm has unique managerial capabilities (Barney 1986), the capacity to manage these options should be subject to a form of real options analysis that is itself specific to organisational routines and procedures (Miller and Shapira 2004; Helfat and Raubitshek 2000). The term real options decision-making is thus used to infer that organisational and managerial factors have a role to play in exercising and redeploying a firm's portfolio of real options. At the same time, it also needs to be recognised that these real options can affect managerial decision-making and firm specific characteristics indirectly. Significant research has been conducted in this direction to examine the empirical validity of the theory of irreversible investments ${ }^{5}$ in organisations (Vassolo et al. 2004; Folta and O'Brien 2007). This literature emphasises specifically whether managerial decision-making (e.g. regarding entry, exit, alliances or acquisitions) is influenced implicitly by the presence of real options (i.e. relating to delay, growth, switching, etc). Such a form of (real options) decision-making stems from economic rationality principles.

\section{Real Options: Valuation, Heuristics and Capabilities}

In an organisational context, a real option embeds a firm's ability to sequence, stage and reverse commitment in the face of uncertainty and enables it to structure flexibility in operations and strategic investments. This includes the options to wait, scale, switch, expand and abandon (Trigeorgis 1996). Whether written or designed either "on" or "in" investments and operations, real options can be viewed as a technique for decisionmaking and valuation or as (in)tangible resources/assets to be exploited by firms (Scherpereel 2008; Smit and Moraitis 2010). Management literature studies the real options theme under several perspectives depending on the utility of the methodology within organisational and behavioural boundaries (McGrath et al. 2004; Miller and Arikan 2004; Tong et al. 2008a). Distinctions are made between real options valuation, real options reasoning, and real options as capabilities for firm evolution and managerial decision-making. These three streams, as specific lenses ${ }^{6}$ for real options decision-making research, fit under the general umbrella of real options theory. Common to these streams are the specific parameters that drive option value and subsequently shape investment decisions. Besides the usual factors employed in finance to quantify the value of optionality (e.g. underlying asset, exercise price, volatility, riskfree rate and time to maturity) key drivers ${ }^{7}$ encountered in real options research proxy for uncertainty and its components, irreversibility and its implications, and competition effects.

\section{Real Options Valuation}

Real options valuation (ROV), for which examples are provided in texts covering aspects of quantitative decision-making ${ }^{8}$, can be applied to resource allocation

\footnotetext{
${ }^{5}$ See Dixit and Pindyck (1994).

${ }^{6}$ Because valuation effects influence managerial decision-making and managers sometimes behave according to the logic of real options reasoning, these streams are interconnected. Their integration can be strengthened further by considering explicit real options implementation in firms (see Reuer and Tong 2007a).

7 These key option value drivers have received the most attention in empirical strategy and managerial economics research on real options. They determine investment likelihood, timing, mode choice, structure and design etc.

${ }^{8}$ See Mun $(2002,2003)$.
} 
processes or project management activities (Amram and Kulatilaka 1997; McGrath 1998). ROV helps address issues of irreversibility and uncertainty when undertaking investment and optimise decision-making in a dynamic and stochastic world. This procedure measures the option's potential to partly reverse commitment and assesses the benefits of waiting before uncertainty is resolved (McGrath 1997; Anderson 2000). A number of management scholars admit that real options valuation is appropriate for project management and isolated investments appraisal, but argue that it might not be suitable for strategic decision processes and chains where endogenous sources of uncertainty are dominant and option interactions are latent (Coff and Laverty 2001; McGrath et al. 2004; Adner 2007). Difficulties in obtaining the exact proxies for options' inputs sometimes undermine the validity of quantitative options modelling in organisational decision-making (Bowman and Moscowitz 2001; Miller and Waller 2003). This relates also to issues of risk and uncertainty modelling (Miller and Shapira 2004; Borison 2005).

\section{Real Options Reasoning}

Real options reasoning (ROR) is the process of embracing an option-based view of investment decision-making and strategic positioning (Bowman and Hurry 1993; Miller 2002; McGrath and Nerkar 2004). ROR highlights the notion of proactive planning and the ability to consider alternatives during any planning and strategy formulation situation. The main contribution of the methodology, which serves more as a strategic mapping procedure than a valuation exercise, is that decision-makers acquire competences for sequencing commitment in a foresightful and incremental/flexible manner. ROR focuses on value creation and resource reconfiguration rather than optimisation and value maximisation (McGrath and MacMillan 2000; Miller and Arikan 2004). Real options are implemented as heuristics for shaping the strategic agendas of organisations and as structuring/directional tools for future commitment decisions (Luehrman 1998b; McGrath et al. 2004). Strategic processes involving resource (re)allocation are viewed under the option logic, while flexibility (i.e. having reversible alternatives) is intuitively embedded in the design of investments and operations. Real options reasoning, or real options thinking, can be used either as a specific planning technique or an intuitive decision-making metaphor (McGrath et al. 2004; Power and Reid 2006). This form of real options decision-making used to be the dominant view of real options in strategy and management research. However, there is a growing trend in the area to move beyond real options reasoning and examine in a positivist sense the antecedents of real options decision-making/investments and the performance outcomes of real options in firms (e.g. Lee et al. 2008; Chung et al. 2010). This can help direct research towards more evident aspects of decision-making in particular processes of real options implementation and exercising, and the role of decision-makers in real options attentive firms (Reuer and Tong 2007a; Barnett 2008).

\section{Real Options as Capabilities to Influence Decision-making}

A more complete approach towards real options decision-making is adopted by Kogut (1984, 1985), extended to some degree by Bowman and Hurry (1993), and refined by Kogut and Kulatilaka ${ }^{9}$ (1994b, 2001). They posit that real options should be perceived as platforms for organisational learning and view them as investments in new

\footnotetext{
${ }^{9}$ This concerns both the antecedents of real options investments and firm real options outcomes under a strategy formulation lens.
} 
capabilities that enable firms to reverse their organisational inertia, create value, and sustain competitive advantage. The exploitation of these platforms will depend on the implicit or explicit influence of real options on decision-making, which suggests there are heterogeneities in capturing such effects (Kogut and Chang 1996). By acquiring the necessary knowledge for adapting to uncertainty a firm can develop systems and practices to benefit from the variance of operations as well as exploring and exploiting new opportunities (Kogut 1985; Kim and Kogut 1996). The firm enters an evolution life-cycle where knowledge is a core competence and learning is a source of competitive advantage (Miller 2002). The real options paradigm helps to link the firm's stages of evolution in the face of uncertainty (Kogut and Kulatilaka 2001). The constant reconfigurations of resources, and therefore the required renewal of core competences, are mechanisms that should be triggered by the firm's real options capabilities ${ }^{10}$ (Kogut and Kulatilaka 2004). This perspective of real options logic converges towards theories of complexity, organisational inertia and the dynamic capabilities view (DCV), but is also partly in line with theories of rational behaviour. Empirical research investigating firm investment decisions and issues of timing and real options structuring (e.g. Folta and O'Brien 2007; Chi and Seth 2009) can be categorised in this stream of literature, especially with regard to the impact and interactions of embedded options on strategy formulation decisions (Folta and O'Brien 2004).

The above perspectives summarise the established views regarding the concept of real options in management and strategy research, and clarify what a real option can represent in managerial mindsets and in organisations. Real options can be viewed as an explicit/implicit technique for decision-making and valuation, a logic for strategic planning, or as (in)tangible resources/assets to be exploited by firms. The next section uses these perspectives to discuss motives and dynamics behind real options investment and decision-making.

\section{The Uncertainty-Flexibility Relationship}

The main essence of real options is that they confer on owners the ability to partly reverse commitment and to postpone decision-making until additional information is available. The design of the option allows its holder to benefit from uncertainty only in the occurrence of favourable events (McGrath 1997). It is this asymmetry that determines the value of the real option and impacts on performance. The gains made from cost reallocation and the advantages of the wait-and-see strategy are factors establishing the amount of flexibility embedded in an option-based commitment. It is uncertainty that generally determines the scale of this asymmetry, and therefore real option value. The stochastic fluctuations of operating and economic environments can originate value if investments are managed flexibly or in an option-based way (Kogut $1985,1989)$. It is this feature that makes the real option topic relevant to the economic and organisational sciences; uncertainty can be a source of value rather than cost (McGrath 1999; Trigeorgis 1996). Real options can work as hedging tools against adverse volatility or growth generators in the face of uncertainty (Amram and Kulatilaka 1997; Oriani and Sobrero 2008). Thus, real options decision-making can be considered an appropriate management framework for coping with an ever changing world (Kogut and Kulatilaka 1994b, 2004). The uncertainty-flexibility relationship can become a source of value if options are recognized and exercised in an optimal manner

\footnotetext{
${ }^{10}$ Barnett (2008) frames these arguments within an attention-based view of decision-making and studies the structural conditions behind options exploration and exploitation in firms.
} 
(Kogut 1985; Triantis 2005; Barnett 2005). Uncertainty creates possibilities while flexibility helps to dynamically explore, structure and exploit these opportunities subject to sources of exogenous and endogenous uncertainty (Buckley and Tse 1996; Garud et al. 1998; Petersen et al. 2001). Examples of exogenous factors affecting decisions might include competitors' actions, technological innovation and macroeconomic elements of business environments (Sanchez 1995; Folta 1998; Miller and Waller 2003). Cases of endogenous uncertainty concern stochastic discontinuities occurring in firm operations, which comprise operational and organisational hazards (Garud et al. 1998; Sanchez 2003).

Several types of flexibility decisions (e.g. to wait, switch, abandon, extend, and scale down) can be structured through real options in planning processes as a way of handling instability and unpredictability. The firm generally holds a portfolio of strategic (growth) and operating options, or strategic and operating flexibility capabilities, which predisposes it to benefit from upside opportunities and mitigates its downside risk (see Trigeorgis 1996 for further details). If designed, integrated and managed correctly, real options should logically add value to firms. However, it should also be remembered that real options, and real options decision-making, requires adjustment and coordination expenses that an organisation might not always be willing to tolerate. Resources are limited and commitment might sometimes be preferred over flexibility (Barnett 2003).

\section{The Commitment-Flexibility Trade-off}

There is an apparent consensus in the management literature about the organisational and behavioural imperfections of real options in the decision-making processes of organisations (Janney and Dess 2004; Philippe 2005; Coff and Laverty 2007). Real options as resources or logic cannot be advantageous on a universal basis because it is the decision to exploit flexibility platforms that leads to value creation and not only the firm pool of shadow options (Bowman and Hurry 1993; Barnett 2005). Commitment can be more beneficial if managers and stakeholders realise that real options decisionmaking does not suit organisational boundaries (Janney and Dess 2004; Fichman et al. 2005; Tiwana et al. 2007). In fact flexibility can destroy value if corporate systems are not equipped with adequate tools to benefit from optionality (Kogut 1989; Kogut and Kulatilaka 1994b; Rangan 1998). In addition, commitment can be of strategic value if undertaken for pre-emptive objectives (Smit and Trigeorgis 2007; Dalziel 2009). Therefore, every firm should assume there is a trade-off between its commitment and flexibility capabilities ${ }^{11}$ ( $\mathrm{Li}$ and $\mathrm{Li} 2010$ ). It is the optimal management of this trade-off that generates value and sustains competitive advantage. The uncertainty-flexibility relationship only creates the necessary landscape for an exploration of strategic and operating opportunities; the level of subsistence of such trade-offs determines how well value has been exploited (Chi 2000). Naturally, the size of the trade-off is related to a firm's exogenous and endogenous risks (Cypers and Martin 2010), which also concern industry effects, agency and organisational issues (Adner and Levinthal 2004b; Coff and Laverty 2007; Markman et al. 2009). A wait-and-see strategy might not be valuable in a market where first-mover advantages can be substantial. For instance, high uncertainty industries operate in high growth markets where only a few players (firstmovers) are able to capture the best opportunities. First mover advantage can also lead to strategic pre-emption and therefore enables firms to protect their future growth

11 i.e. tensions between exploration and exploitation. 
options through patenting or other exclusivity rights (Folta and O'Brien 2004; Smit and Trigeorgis 2004). As a result, a distinction is made in the literature between company proprietary and shared options. The latter represent opportunities that can be exploited by several industry players and generally increase the speed of early commitment during periods of high uncertainty (Trigeorgis 1996; Folta and Miller 2002). On the other hand, proprietary options facilitate the exploitation of the wait-and-see strategy (Tong and Reuer 2006). Next we discuss how the above principles are integrated in strategy and multinational business research.

\section{Real Options in Corporate Strategy and International Operations}

This section provides an overview of the conceptual research themes framing the real options perspective within theories of the (multinational) firm. Section 3.1 focuses on the strategic factors explaining sources of competitive advantage. Section 3.2 sheds light on foreign direct investment modes and the flexibility potential of multinational networks and operations.

\section{Real Options in Strategic Decision-Making}

One of the main objectives of strategic management research is to elucidate the "why" and "how" of corporate decision-making (Leiblein 2003). It focuses on the heterogeneity of managerial competences and investment choices to determine internal and external sources of organisational performance (Colombo 2003). Generally, the real options paradigm provides the appropriate managerial landscape for balancing between the firm's internal and external views in strategy making (Kogut and Kulatilaka 2001; Sanchez 2003; Smit and Trigeorgis 2004).

\section{Real Options and Theories of the Firm}

Several writers have attempted to integrate the paradigm of real options within transaction costs, resource and knowledge based or external theories of the firm (Leiblein and Miller 2003; Pandza et al. 2003; Santoro and McGill 2005; CuervoCazurra and Un 2010). Sanchez (2003) develops an integrative supply and demand uncertainty framework to reconcile transaction cost theory with real options. $\mathrm{He}$ discusses the choice between internalisation and sourcing as a typical illustration of the commitment-flexibility trade-off dilemma and draws attention to the impact of opportunism on strategic flexibility. The role of organisational slack is also underlined as part of this dimension. Leiblein (2003) identifies areas of association between real options theory, the resource based perspective (RBV) and transaction cost economics (TCE) to provide a comprehensive management approach towards governance choice and organisational performance. Foss (1998) discusses the limitations of the resource based perspective and questions the validity of asset specificity in today's unstable environments, arguing that the RBV only emphasises competitive advantage and diversification, and generally overlooks the flexibility potential of operations. He also suggests that the incorporation of real options theory in the RBV can help overcome this inconsistency by shedding light on firms' adaptive and learning capabilities. Similarly, Pandza et al. (2003) and Kylaheiko et al. (2002) explore how the DCV perspective of Teece et al. (1997) can be viewed in terms of real options. Both works underline the significance of uncertainty and knowledge imperfections in managing and structuring resources and capabilities. 
A more normative research stream combines dynamic capabilities and knowledge management theories to signify the vital role of organisational learning in shaping sustainable competitive advantage. More specifically, Bowman \& Hurry (1993) illustrate how investment sequencing helps to generate knowledge for exploration and exploitation. Kogut and Kulatilaka (1994b) develop similar arguments and examine the impact of organisational learning on long-term strategic orientations. Both also explain that investments in flexibility cannot be executed without the evolution of learning competences. The union between flexibility and learning determines how capabilities must be built in anticipation of the future. Kogut and Kulatilaka (ibid.) finally argue that the absence of such a union will generally favour short term thinking among managers. More recently, Helfat and Raubitsheck (2000) discuss how the coevolution of knowledge, products and capabilities can generate options value and result in long-term competitive advantage. Kogut and Kulatilaka (2001) frame real options capabilities as dynamic remedies against organisational inertia. The role of knowledge and managerial competences is stressed as a crucial prerequisite for flexible evolutionary strategies. Miller (2002) extends the knowledge based literature by suggesting that knowledge inventories can be viewed as real options reserves but argues that their optimal exploitation can be undermined by managerial myopia and cognitive bias. Managerial competences tend to determine the size of the gap between shadow and explored options (potential versus actual) (Miller 2002; Miller and Arikan 2004). In a conceptual paper, Boisot and MacMillan (2004) propose several research directions to incorporate real options thinking and scenario planning into knowledge management theories of organisations. Finally, Kogut and Kulatilaka (2001), Smit and Trigeorgis (2004) and Sherpereel (2008) discuss how real options can serve as linkages between firms' internal resources and external opportunities. Smit and Trigeorgis $(2004,2007)$ build a comprehensive game theoretic framework to integrate real options analysis in strategic management. They purport that the real options approach can be a disciplinary intersection between two conflicting strategy paradigms; the resource based view (Wernerfelt 1984) and the external theory of the firm (Porter 1990).

Two main drivers can explain the treatment of real options theory within current strategic management perspectives. First is the necessity to set disciplinary boundaries for the application of real options to business strategy (Adner and Levinthal 2004b). Despite a clear theoretical potential, it is difficult to translate and transfer concepts from finance to corporate strategy without looking at the organisational implications of the approach on firms' systems and procedures (Kogut and Kulatilaka 2004). Financial economics models do not generally capture a detailed/full picture of a firm's sets of internal processes, although complexity, agency and path-dependency problems do shape governance modes and investment choices. It is up to strategy scholars to unite real options concepts with strategic management assumptions. Naturally the expectation is that it will be done with a bias towards behavioural and procedural considerations. Second is the fact that real options and corporate strategy share a common research theme; the determinants of corporate performance. Resources and strategic investments can be viewed as real options (Trigeorgis 1996) while governance modes and strategic positioning decisions embed real options chains (McGrath 1998; Burger-Helmchen 2009). Rightfully, the advantage of the management lens is that it pays more attention to learning, managerial competences and endogenous uncertainty. Strategic options decisions apply generally to market entry modes, forms of governance and innovation investments. Therefore, corporate performance is a function of the 
structure and sequential design of these types of decisions (Folta and O'Brien 2004; Kumar 2005).

\section{Choice of Governance Modes and Strategic Positioning Decisions}

Market entry and governance options deal with the timing, organisational forms and evolution of the investment decision. Current research on the subject investigates mainly the internal and external drivers of this category of strategic investment (Chi and McGuire 1996; Chi 2000; Brouthers et al. 2008). It shows that industry and firm specific factors confirm the validity of the commitment-flexibility trade-off, which is shaped by transaction costs and learning considerations.

\section{Market Entry and Exploration Decisions}

The incremental design of market entry and exploration strategies creates value through flexibility, providing benefits from deferral as well as growth from learning. Chang (1995) and Kogut and Chang (1996) examine the impact of organisational learning on firms' sequential entry processes, showing how knowledge and path-dependencies can help diversify operations into non-core businesses. Petersen et al. (2001) discuss the implications of strategic flexibility on companies' international entry modes and highlight advantages of shifting operating modes during exploration activities. Chang and Roseinzweg (2001) investigate the effect of transaction costs and cultural factors on sequential foreign entry and show that experience in modes of entry can alter the determinants of investments. Raynor (2002) interprets business diversification as investments in real options, suggesting that diversifying to non-core businesses provides strategic hedging instruments against convergence phenomena. Others adopt a more disciplinary and positivist approach towards entry and exploration. Miller and Folta (2002) explicitly discuss entry timing decisions through a real options lens and underline the conflicting trade-off between flexibility and commitment for market entry investments. Folta and O'Brien (2004) extend their framework and study tensions between growth and deferral when firms go into new industries, while Vassolo et al. (2004) shed light on the non-additive feature of option exploration portfolios and validate the existence of options interactions in the presence of multiple options. Folta et al. (2006) assess the effect of irreversibility and uncertainty on the likelihood of the option to defer, and finally, Leiblein and Miller (2003) and Villalonga and McGahan (2005) study the impact of transaction costs, firm specific capabilities and real options on the choice of governance modes of exploratory operations. Other existing research emphasizes the role of cooperative (sequential) deals in shaping growth option opportunities (Xu et al. 2010).

\section{Collaborative Ventures}

Collaborative ventures/contracts can be considered as structuring instruments for dealing with risk and uncertainty. They confer the freedom to terminate collaboration in cases of adverse hazards and are used by corporations as learning tools for market entry, technology acquisition and cooperative (in)competence development (Nanda and Williamson 1995; Estrada et al. 2010). The structure of the alliance is generally similar to an option to expand, acquire or divest (Kogut 1991). The option to increase commitment via further expansion occurs if the combination of learning and exploration is valuable. Scholars investigating the area generally analyse the determinants of collaborative agreements, their contractual and performance 
implications, all from a real options, transaction cost and behavioural perspective (Villalonga and McGahan 2005; Santoro and McGill 2005). For instance, Kogut (1991) examines the timing of joint-venture acquisitions during conditions of market uncertainty. Nanda and Williamson (1995) discuss the restructuring potential of jointventures and partnership deals in large corporations. Chi and McGuire (1996) and Chi (2000) investigate how transaction cost effects influence the evaluation of collaborative venturing and market entry and exit options. Folta (1998) and Folta and Miller (2002) study the motives behind the initiation of equity partnerships within a commitmentflexibility argument. Colombo (2003) analyzes variables influencing firms' choice of the organisational form of strategic partnerships under competences and options perspectives. Kumar (2005) studies the flexibility potential of joint-venture divestment on value creation and market positioning. Reuer and Tong (2005) examine the antecedents of explicit call options in JV agreements, suggesting that transaction cost and cultural considerations might dominate motives of flexibility while setting alliance deals. More recently Reuer and Tong (2010) analyse firms' equity alliances with IPO entities, underlining how visibility and growth options potential can be key determinants of alliance formation. Other studies within the same agenda include Chen et al. (1991) and Tong et al. (2008a).

Overall, it is argued that sequential market entry/exit and collaborative investments confer firms with flexibility potential that one-shot commitment strategies do not have. However, this flexibility can be inhibited by external and internal forces that a company must assume. Then it is up to options exploitation and managerial competences to create full value and shape competitive advantage. Innovation and R\&D investments are examples of resources that require the amalgamation of both attributes (Faulkner 1996; Newton et al. 2004; Chi and Levitas 2007; Oriani and Sobrero 2008). Another area in which real options can be found is operations networks, particularly for MNCs because the size and breadth of international operations provide them with strategic and operating options that domestic firms usually do not have. Theoretically, the scope and value of such flexibility increases with foreign investments. The flexibility advantage of MNCs constitutes a fundamental theme in real options management research.

\section{Real Options in Multinational Operations}

Internalisation and the multinational network hypothesis (MNH) are two dominant views that analyse the performance of MNCs in multinational business research (Pantzalis 2001; Li 2007b). Internalisation builds upon transaction costs and resource based arguments to explain firms' tendency to integrate resources in international networks. Complexity, opportunism, cultural uncertainty and market inconsistencies are all factors favouring commitment over flexibility in foreign operations (Buckley and Casson 1998). Internalising resources within operations systems enables protection against exposure to the flaws of sourcing and contracting (i.e. falsification and suboptimal collaboration). On the other hand, the MNH views MNC networks as a wide portfolio of real options that confers them with hedging opportunities to mitigate losses and benefit from uncertainty (Kogut 1984, 1985). The geographical dispersion of operations and the heterogeneity of foreign markets create value from growth, arbitrage and flexibility prospects. The dynamic version of the $\mathrm{MNH}$ aligns with the theory of real options (Buckley and Casson 1998). 


\section{Real Options and the 'Multinational Network Hypothesis'}

Under the dynamic MNH, growth and operating options are available to MNCs and are driven mainly by the stochastic fluctuations of operating environments and the incompleteness of foreign markets. Options originate from location advantages, foreign exchange arbitrage, tax regimes and labour cost differences, as well as growth opportunities from emerging markets (Harris et al. 1993; Allen and Pantzalis 1996; Pantzalis 2001). The exploration and exploitation of these options determines long-term performance. This idea of dynamic international management is not necessarily captured by internalisation theories (Verbecke 2003). Indeed, Kogut's MNH underscores uncertainty as a source of value rather than cost, suggesting that sequential commitment (flexibility) can be better than internalisation. Kogut $(1984,1985)$ posits that international corporations can be viewed as having diversified options portfolios that generate value through learning and (multinational) operating flexibility. Operating options flexibility enables MNCs to benefit from the variance of current operations while learning generates growth opportunities through sequential entry and investment modes (Kogut 1984, 1985; Buckley and Casson 2004). The wait-and-see feature of real options can confine growth potential that would be foregone under internalisation and offers platforms for deferral, contracting, shifting and abandonment that transaction costs considerations might not encourage (Rivoli and Salorio 1996). However, Kogut (1984) hints that real options might not be valuable unless firms acquire the necessary knowledge, managerial and adaptive capabilities to implement flexibility in their systems, so there may be a gap between their actual and potential benefits from multinationality (see also Tong and Reuer 2006). Other scholars argue that such adoption might become more complicated with internationalisation (Rangan 1998; Reuer and Leiblein 2000; Tong and Reuer 2007a). In fact coordination and adjustment costs will be incurred in the overall chain of network activities to make flexibility exploitable. That is why Kogut $(1984,1985)$ never dissociates learning from real options. Also options can influence decision-making and not only the opposite (e.g. Belderbos and Zou 2009), but whether flexibility value is exploited fully still remains to be seen. We now discuss existing research on the decision-making and performance implications of real options in the management of international operations, where distinction is made between strategic and operating options (Campa 1994; Chung and Beamish 2005).

\section{Strategic Flexibility and Growth Options}

Multinational growth options embody all market entry decisions and resources related to foreign direct investments (e.g. Li and Rugman 2007; Fisch 2008; Gulamhussen 2009). They can take the form of acquisitions (Brouthers and Dikova 2010), greenfield projects, partnerships or joint-venture agreements and can also be localised in learning and deferral decisions. Strategic growth options are compound options for future international activities (Jiang et al. 2010). Doukas and Travlos (1988) investigate the impact of international acquisitions on shareholders wealth, finding that option value only exists when MNCs diversify operations in new geographic areas and non-core business segments. Chen et al. (1991) examine the wealth effect of US joint-ventures in China, showing how establishing sequential investments in new markets can generate excess returns to shareholders. Chang (1995) underlines the benefits of foreign sequential entry processes on the evolution of Japanese multinationalism in the US. Campa (1994) evaluates the effects of foreign exchange (FX) and demand uncertainty 
on decisions to expand capacity in a particular country. Using similar arguments, Rivoli and Salorio (1996) show why FDI deferral can be more valuable than ownership and internalisation in the presence of irreversibility and uncertainty. McCarthy and Puffer (1997) compare six different investment strategies for market entry in Russia, illustrating why flexibility or commitment might not be a matter of choice when considering entry decisions in uncertain environments. However, Petersen et al. (2001) argue that designing flexibility in the structure of foreign investment modes can protect firms from negative hazards. Pantzalis (2001) studies the relationship between market valuation and the scope of international operations in US MNCs, agreeing with Kogut's options portfolio analogy (Kogut 1991) and Doukas and Travlos (1988). More recently, Tong and Reuer (2005) examine the antecedents of explicit call options in JV agreements, suggesting that transaction cost considerations might dominate motives for growth when setting up cooperative deals. Tong et al. (2008a) extend their findings by investigating the determinants of growth option value in international joint-ventures. Other studies cover the performance implications of investment modes in an option context (Chung and Beamish 2005; Denning et al. 2006; Chi and Seth 2009) or simple motives behind the settlement of international cooperative ventures (Cuypers and Martin 2006, 2010).

Generally, the literature suggests that foreign operations create growth prospects for MNCs. Besides influencing decision-makers choices, strategic options can be designed in the structure of international investments to exploit such prospects. Sequential entry processes and learning capabilities allow firms to capitalise on the value of waiting while exploring upside opportunities (e.g. IJVs). Yet the real options logic can be undermined by systemic, transaction costs and cultural considerations that may favour commitment and inertia over multinational flexibility.

\section{Operating Flexibility and Real Operating Options}

Real operating options represent the hedges a firm has to exercise within its internal operations to reduce corporate exposure and downside risks. In the context of internationalisation they can take several forms. Some cases of flexibility that allow the firm to protect its risk exposure from downside movements include the options to shift operations between countries after adverse shocks in exchange rates or options to delay production or shut down operations after a sudden decline in market demand (Trigeorgis 1996; Reuer and Leiblein 2000). The option to outsource operations to a low cost location is another example of the flexibility of international operations (Leiblein and Miller 2003; Mol et al. 2005). Generally, it is the spread of overseas activities that determines international operating flexibility potential. Muralidhar (1992) develops a capacity choice application for production shifting under conditions of labour and input uncertainty. Kogut and Kulatilaka (1994a) derive a more general model and underline the impact of coordination costs from foreign exchange shifting on the value of growth and operating flexibility. Other studies focus on more theoretical arguments and discuss the microeconomic implications of internationalisation on production flexibility and hedging policies (e.g. De Meza and Van Der Ploeg 1987; Mello et al. 1995). Elsewhere, writers discuss the ability of real options to reverse and change tactical directions in the face of uncertainty (Capel 1997; Buckley and Tse 1996; Belderbos and Zou 2009). Capel (1997) explores potential to reduce economic exposure under a real option lens, while Buckely and Tse (1996) illustrate how the 
incorporation of real operating options in FDI structures can overcome the flaws of traditional planning techniques through flexible dynamic management.

Given this context, empirical international decision-making research on real options has attempted to investigate whether or not, and to what extent, dimensions of flexibility are recognised and exploited in MNCs (e.g. Rangan 1998; Dhanani 2004; Aabo and Simkins 2005; Tong and Reuer 2007a). Overall, the general finding is that multinationality through real options embeds options value for multinational firms. Nevertheless, the optimisation of flexibility is not an easy task due to potential coordination and transaction costs that must be incurred because of real options design and maintenance. Learning and systemic adaptability are required for the appropriate exploitation of strategic and operating options, but due to the constant difficulty in solving the commitment-flexibility dilemma there is a debate in management research on the validity of real options theory and its application to decision-making in strategy and international management. Three main views dominate existing literature on the subject, i.e. real options optimism, real options pessimism and real options realism. Arguments from these three perspectives are discussed in the following section.

The Real Options Debate

Research that takes a critical stance towards the incorporation of real options theory into strategy and multinational management revolves around two interrelated arguments. First, the organisational implications of real options decision-making can be negative for internal processes and current practices. Investments in real options are able to distort a firm's commitment-flexibility trade-off into distressful flexibility positions (Barnett 2003). Second, the difficulty in generalising real options modelling solutions in corporations makes the concept hard to accept by practitioners (Busby and Pitts 1997; Janney and Dess 2004). Optimists on the other hand argue that it is only learning by doing that will enable corporations to manage their strategic options portfolios optimally (McGrath 1997, 1999). Real options opportunities must be explored and exploited continually to generate long-term returns from project investments (Luehrman 1998a). Cautious about the systematic benefits of real options, real options realists embrace a more consensual position and instead frame flexibility within organisational and behavioural boundaries (see Tong and Reuer 2007b; Reuer and Tong 2007a). Flexibility only has value if there are adequate levels of knowledge, tools and resources to dig for options prospects (Rangan 1998). Learning and organisational change are prerequisites for a firm's flexible evolutionary strategies (Kogut and Kulatilaka 1994b, 2001).

\section{Real Options Pessimism}

Scholars casting serious doubt on the validity of real options in strategic investments emphasize the unsuitability of the approach to organisational boundaries (Adner and Levinthal 2004a, 2004b). They argue that flexibility in planning processes can be abused because of managers' bounded rationality and firms' cultural heritage, hence making the real options logic ineffective and too complex/dangerous for major commitment decisions. Practical and industrial considerations are other elements that strengthen this view (Ryan and Ryan 2002; Miller and Shapira 2004). Coff and Laverty (2001) build upon the problem of optimal exercising to show that real options planning can be influenced by agency considerations, which will make options projects difficult to integrate in operations. They posit that social ties and cognitive biases generally lead 
to suboptimal exercising and flawed decision-making. Coff and Laverty (ibid.) cite examples of Xerox and 3M as typical of suboptimal real options decision-making and management, concluding that the real options approach might be too risky to implement in core activities. Carr (2002) adopts a similar position and highlights the tendency of real options thinking to escalate commitment in the face of abandonment. Adner and Levinthal (2004a, b) also emphasize the flaws of abandonment and stress the organisational obstacles for real options as well as dangers of application to business strategy. Both studies use arguments from transaction costs and agency theories to underline domains and functions where real options should not be integrated. It is argued that real options analysis only works well for isolated project management activities. Barnett (2003) is also critical of the noncommittal nature of real options decision-making, claiming that too many explored options convey a lack of business focus to stakeholders and reduce intangible market value. Barnett also describes the managerial and behavioural pitfalls of flexible decision-making on internal resources and processes while flexibility is judged to sometimes harm productivity and core competences (Barnett, ibid). Barnett concludes that it is simply unrealistic to embrace flexibility without completely altering systemic hierarchies and operational routines. Finally, Borison (2005) and Philippe (2005) examine the limitations of quantitative real options modelling in practice.

\section{Real Options Optimism}

This research strand focuses on the strategic and financial gains made from incremental commitment. Flexibility is claimed to enhance corporate performance and upside potential. The real options approach, though requiring a premium for optionality, increases the likelihood of growth discoveries and downside risk mitigation (Trigeorgis 1996). It also provides the disciplinary instruments for managing projects in an active and forward-looking manner. On one hand, the wait-and-see strategy allows decisionmakers to partly reverse investments with new information arrival, while on the other hand sequential commitment creates knowledge platforms for growth exploitation (Kogut 1984). Firms with real options investments are more likely to exhibit some kind of competitive advantage because of diversified projects and alternative adaptive strategies (Amram and Kulatilaka 1997). McGrath $(1997,1998)$ extends this theory to corporate strategy by analysing technology management processes, drawing upon the asymmetric features of real options to derive sources of uncertainty from technology positioning investments, concluding that sequential processes, as well as deferral, grant firms amplifying preinvestments for future commitment decisions. McGrath also explores the implicit benefits of options' abandonment in entrepreneurial failure (McGrath 1999). Luehrman (1998a) imagines how strategy can be viewed as a real options portfolio and Andersen (2000) highlights the features of real options reasoning when dealing with postponement and abandonment, while Zardookhi (2004) and McGrath et al. (2004) explain why real options theory is useful to strategic management. Zardookhi (2004) disputes Adner and Levinthal's (2004a) arguments by suggesting that their descriptions of option pathologies are unlikely to happen in profit maximising firms, claiming that they have enough monitoring mechanisms to control for chaotic flexibility and hence manage options properly. McGrath et al. (2004) argue that the real options logic should not be removed from its theoretical context because it offers valuable guidance for strategic decision-making. Real options decision-making helps to plan specifically for contingencies, structure future investments and capitalise on uncertainty proactively, which makes the underlying theory essential to the dynamic 
capabilities and evolutionary views of the firm. However, they admit that practical, but not axiomatic, matters might damage endorsement (McGrath et al. ibid).

\section{Real Options Realism}

Real options realism considers that flexibility should be explored or planned before being triggered, which means that firms must be equipped with knowledge, systems and capabilities to detect or implement real options in operations before starting exploitation (Rangan 1998; Kogut and Kulatilaka 2004). This requires significant changes in managerial routines, procedures and cost structures (Reuer and Tong 2007a). The evolution of learning and dynamic managerial competences is the major factor leading towards the reversal of organisational inertia (Kogut and Kulatilaka 2001). Garud et al. (1998) summarise this point in a response to a study by McGrath (1997), suggesting that only organisational design and dynamic capabilities can realise option value. Without them, there is no difference between effective and illusionary real options (Garud et al. 1998). This specific argument is refined and developed by more recent studies (e.g. Miller 2002; Miller and Arikan 2004; Barnett 2005, 2008). Resource availability and knowledge evolution are identified as necessary remedies to make firms absorb the full potential of their options' reserves. Within more practical settings, Bowman and Moscowitz (2001), McDouglas and Pike (2003) and Janney and Dess (2004) all discuss ways of reducing the flaws of real options implementation in industry. In particular, Miller and Waller (2003) and Janney and Dess (2004) recommend the institutionalisation of group decision-making and external review procedures to increase real options awareness in corporations and reduce managerial bias and adventurism during project appraisal. Coff and Laverty (2007) also defend this point but admit that organisational and disposable costs weaken optimal option exercising. They discuss various strategies for minimising such costs and finally suggest that investments in knowledge-based assets should be subject to real options analysis. Finally, Adner (2007) underscores the structuring merits of real options in resource reallocation processes but warns against managerial tendencies to confuse unstructured path-dependencies and authentic real options. Also, it should be borne in mind that existing quantitative research is evolving towards real options realism (Vassolo et al. 2004; Fichman et al. 2005, Tserlukevich 2008).

The following section discusses the current evidence concerning the implications of real options theory in organisational decision-making, which suggests that real options realism is the prevailing view in the empirical literature (see Reuer and Tong 2007a for a detailed review of the evidence). Though managers are able to recognise the options embedded in operations and strategic investments, the option metaphor/logic can prove to be incomplete once knowledge acquisition and capabilities integration are not performed in firms' infrastructures and operating systems.

\section{Empirical Evidence}

In this paper empirical evidence on real options decision-making has been categorised into two main areas; 1) statistical research studying the determinants of real option investments and implications of real options performance (e.g. O'Brien and Folta 2009; Lee and Makhija 2009a), and 2) exploratory research investigating the adoption of real option practices in industry (e.g. Block 2007). Empirical work devoted to the validation of existing financial economics models is excluded from this review (e.g. Paddock et al. 1988; Quigg 1993; Berger et al. 1996; Oriani 2007). 


\section{Statistical Findings}

Generally, statistical studies investigate the implicit and explicit antecedents of optionality as well as impacts of real option resources on performance and decisionmaking. Other similar work examines evidence of sequential planning and flexibility in firms' management and investment behaviour. Several articles are devoted to theories of MNCs because of the flexibility potential of international operations and the significant debate on real options in large firms. Research in this area concentrates on the uncertainty-flexibility and performance linkage. First, there are studies examining the main factors behind flexibility and investment, and more specifically the determinants of real options investments (Campa 1994; Bulan 2005; Folta and O'Brien 2006). Second, there is empirical work that analyses the performance implications of real options. Researchers have studied especially the impact of multinationality, jointventures, operating and strategic flexibility on corporate performance, downside risk and growth proxies (Reuer and Leiblein 2000; Tong et al. 2008a, 2008b). Research from both sub-streams relies on secondary data analysis to test the validity of real options theory as a decision-making framework or an implicit economic logic for investment under uncertainty (e.g. Folta and O'Brien 2007, Power and Reid 2006). There is no particular study which explicitly inspects the generalised effect of real options decision-making, or at least real options knowledge, on performance or the structural interactions between real options determinants and firm performance outcomes. This is due mainly to the reluctance of firms to disclose in detail the "how" and "where" of their specific real options capabilities and also explains the scarcity of statistical survey research on the explicit risk/value dynamics of real options and their exercising properties.

\section{Determinants of Real Options Investments}

As discussed earlier, there are specific market and organisational parameters that justify the (implicit) employment of options-like decisions in undertaking and managing investments. Uncertainty, irreversibility, growth, tax and location advantages are all factors influencing investment behaviour (e.g. O'Brien and Folta 2009). Harris et al. (1993) present evidence of location-driven shifting among US MNCs, suggesting that they conduct income shifting for tax and risk related purposes (Harris et al. 1993). Kogut (1991) investigates the effect of product market indicators on the likelihood of joint-ventures acquisitions and shows that unexpected growth signals do trigger the JV expansion option. Chang (1995) and Chang and Roseinweg (1998) study the impact of sequential foreign entry modes on the business expansion of firms and validate the hypothesis of capability building via sequential learning. This hypothesis is also verified by McGrath and Nerkar (2004) in the context of pharmaceutical R\&D. Rangan (1998) analyses MNCs' tendencies to shift sourcing and production in the face of foreign exchange fluctuations, discovering that firms in the Triad regions operate flexibly, but only react moderately, to currency exposure. Kouvelis et al. (2001) study the determinants of production strategies adopted by US firms entering foreign markets. The authors identify exchange rate risk and market power as factors explaining switching inertia. Findings also suggest that the choice of ownership structures (i.e. IJV, export entreprises or wholly owned subsidiaries) varies according to exchange rates fluctuations with a preference towards non-committal and reversible modes of production (Kouvelis et al. ibid.). Folta (1998) and Folta and Miller (2002) examine factors behind the acquisition and non-acquisition of equity partnerships in the 
biotechnology sector, while Folta (1998) demonstrates that growth and learning motives favour incremental governance modes over acquisition in the presence of uncertainty, although there are exceptions to this rule if risks of pre-emption and erosion are dominant (Folta and Miller, 2002). Folta and O'Brien (2004) corroborate these conclusions by underlining the non-monotonic effect of uncertainty on market entry, with their evidence also revealing that options' interactions (i.e. growth versus deferral), managerial capabilities ${ }^{12}$ and firm specific factors influence strongly the decision to invest. Vassolo et al. (2004) examine the impact of options' interactions on exploratory activities and confirm that firm specific factors have a role in investment and divestment decisions. Leiblein and Miller (2003) study the relationships between vertical integration, asset specificity and uncertainty in the semiconductor industry, finding that flexibility may be preferred to integration under combined conditions of high uncertainty and low asset specificity. Similar conclusions are reached by Colombo (2003) from the perspective of technology alliances. Tong and Reuer (2006) measure statistically the weights of industry and firm effects on the value of growth options. Outputs from variance decomposition show that firm specific factors dominate industry effects (Tong and Reuer 2006). These results strengthen the view that real decisionmaking can be central to real options value (e.g. Aabo and Simkins 2005; Guler 2007). Economic studies investigating the relationship between uncertainty and investment draw similar conclusions and also validate partly the theory of irreversible investments (e.g. Driver and Whelan 2001; Bulan 2005; Shaanan 2005; Folta et al. 2006). Table 1 highlights and categorises the main empirical studies concerned with the determinants of real options investments in light of three views (i.e. optimism, realism and pessimism) presented under the real options debate.

\section{[Insert Table 1 here]}

Overall, empirical evidence examining the antecedents of real options suggests that opportunities exist in strategic investments and operations. They are taken implicitly into account by managers when dealing with governance modes and the timing of commitment decisions as uncertainty and irreversibility are fundamental to option value. The realisation of such value depends on the interaction between a firm's internal and external factors (Tong et al. 2008b). The main methodological caveat of the aforementioned research lies in the use of numerous, usually uniform, samples to test whether stochastic parameters, irreversibility and competition affect investment behaviour. It is only recently that scholars have underlined the weight of specific and heterogeneous factors in the investment decision (Shaanan 2005; Tong and Reuer 2007b; Aabo and Simkins 2005; Folta and O'Brien 2007). Consequently, real options performance should be determined by company resources, learning and managerial capabilities, as well as flexibility or real options proxies, with real options knowledge also playing a role (see Miller 2002). This too would concern the antecedents of explicit options exercising in organisations.

\footnotetext{
${ }^{12}$ More recently, Folta and O'Brien (2007) statistically verify how managers lower their acquisition thresholds in the presence of growth options.
} 


\section{Performance Implications of Real Options}

Research on the performance implications of real options examines the impact of growth and operating options on market value and returns, currency exposure and organisational downside risks with specific attention paid to the impact of multinationality and uncertainty on corporate prospects. Doukas and Travlos (1988), in a study of the effect of international acquisitions on the stock prices of US bidding firms, find that positive abnormal returns to acquisitions occur only when they enter new segments and new geographic markets. Chung and Charoenwong (1991) shed light on the association between growth options and equity beta risk, and confirm the positive relationship between both constructs. Chen et al. (1991) test for a similar connection but focus on international joint-ventures and excess returns, proving that establishing IJVs in a foreign location creates positive wealth gains for shareholders. Allen and Pantzalis (1996) investigate the impact of multinational breadth on the value of operating flexibility and validate the positive MNH. Miller and Reuer (1998a, b) explore the hedging effect of FDI on currency exposure. Results show a moderate asymmetry with such exposure, as well as a negative association between FDI and FX risk. Reuer and Leiblein (2000) investigate the impact of multinationality and IJVs on organisational downside risks. Their evidence contradicts $\mathrm{MNH}$ and real options theory predictions of downside risk reduction. Pantzalis (2001) examines the relationship between market value and MNCs' geographic scope, illustrating specifically the positive association between growth options potential and firm involvement in emerging economies. Alonso et al. (2005) test the validity of real options theory in stock markets, showing that companies' real options, with the exception of geographic diversification and size, are positively related to market value. Ramezani et al. (2002) examine the relationship between growth and profitability, suggesting that, after reaching a certain threshold, such a relationship might not be linear after all. More recently, Reuer and Tong (2007b) have studied the antecedents of growth option value in corporate investments, providing evidence for the significant contribution of $R \& D$ and international joint-ventures in the value of growth options, although this is not true for investments in acquisitions and tangible capital. Tong et al. (2008a) analyze whether or not firms are able to capture the growth option value of their international jointventures, discovering that only minority and diversifying joint-ventures are able to do so. Tong et al. (ibid.) also challenge claims that IJVs in emerging economies constitute a significant portion of growth option value, suggesting that the absence of such association might be due to the amplifying effect of transaction and cultural costs on downside losses. Tong and Reuer (2007a), studying the effect of international switching options on downside risk, explain that the curvilinear relationship between performance and internationalisation is also due to transactions and coordination matters, revealing that international expansion can reduce risk up to a specific level of geographic depth only. They also reveal that managerial capabilities, which might include the exercising of real options, influence real options performance to a similar extent as resources and international investments (Tong et al. 2008b). Finally, Lee and Makhija (2009a, b) examine the determinants of real options flexibility value during crisis phenomena, partly validating the logic of real options under abnormal uncertainty. In light of the real options debate, Table 2 highlights and categorises the main empirical studies covering the performance implications of real options in light of the three views (i.e. optimism, realism and pessimism) presented under the real options debate. 
[Insert Table 2 here]

To summarise the above findings, it can be said that empirical research on the performance impact of real options usually tests the effect of indicators on accounting, economic and financial value (i.e. multinationality, assets in place, growth, alliances and JVs). In general, evidence suggests that firms' real options have potential to enhance performance and reduce corporate exposure or downside risk. Yet this statement is only complete once managerial competences and resources, e.g. intangible knowledge and specific factors, are included in the value equation. Most studies investigate the impact of real option proxies and the real options logic on performance but do not account for firm specific factors and managerial heterogeneities, which is why existing findings might hold incomplete/conflicting conclusions (e.g. Chen et al. 1991; Allen and Pantzalis 1996; Reuer and Leiblein 2000; Pantzalis 2001; Reuer and Tong 2005; Tong et al. 2008a; Reuer and Tong 2007a). This is consistent with the aforementioned view of real options realism that the real options logic can hold in corporations. It is implicit in managerial decision-making, but differences in execution and resources heterogeneity, including real options knowledge, influence its implications for the performance and design of strategic investments and multinational operations. This implies that differences in sampling and methodology affect the findings of existing empirical research. It is only lately that firm specific factors have been identified as possible determinants of growth option value and performance heterogeneity in MNCs (Tong and Reuer 2006, 2007a; Driouchi and Bennett 2011). According to Kogut $(1984,1985)$, firms in general, and MNCs in particular, can only exploit their flexibility potential when they have developed systems and competences for managing their real options. Before real options capabilities are integrated within a firm's infrastructure and processes, real options knowledge should be acquired and diffused in its headquarters. Therefore, the MNH should be verified on a sample of firms that are able to exploit their real options or at least have a partial capability to do so.

Interestingly there is sufficient, but segmented, evidence of firms developing some kind of capital budgeting skills in real options analysis, mainly through fragmented knowledge acquisition. However, this does not indicate if the real options methodology is used systematically in corporations, although it does provide enough data on firms that have been attentive to their real options, in terms of knowledge and consulting investments, in relation to others that have not.

\section{Real Options in Practice}

A significant number of professional and academic articles provide evidence of the adoption of real option practices in industry or practitioners' interest in the real options "technology" (for references see Smit and Trigeorgis 2004). Table 3 recaps some of the existing cases and managerial surveys on the subject.

[Insert Table 3 here] 
Despite proofs of application, it is speculative to affirm that real options decisionmaking has been institutionalised in these firms. Implementation obstacles, as well as organisational complexity, suggest that they are only relatively aware, to various degrees, of the options embedded in investments and operations. The managerial surveys highlighted in Table 3 discuss practitioners' views on real options analysis and provide additional evidence that a significant sample of firms employ the real options approach to project management and strategic planning/decision-making, or at least acquired significant knowledge about implementing the technique.

There is sufficient evidence from the literature that a significant proportion of corporations have developed skills, know-how, and possibly competences, for real options planning and recognition. However, such implementation has its flaws and is hard to institutionalise (Busby and Pitts 1997; Triantis and Borison 2001). Matters relating to computational difficulty and organisational complexity seem to discourage the adoption of real options in practice (Kemna 1993). For example, Howell and Jagle (1997) and Miller and Shapira (2004) underline the influence of behavioural bias and flawed risk perceptions on managers' intuitive valuation of real options. Though managers are aware of the occurrence of real options opportunities, they might not be able to exploit them because of procedural considerations and short-sighted organisational orientations (Busby and Pitts 1997). Despite being acknowledged as a capital budgeting technique, real options analysis does not yet constitute best practice in firms (Hartman and Hassan 2006). In fact, Ryan and Ryan (2002) reveal that $88 \%$ of the Fortune 1000 corporations included in their survey rarely used the real options methodology for project evaluation, although more positively Block (2007) reports that $14.3 \%$ of the Fortune 1000 firms they examined were using real options methods for capital investment appraisal, while $43.5 \%$ were possibly considering their future use.

These facts underline the heterogeneity of real options decision-making across firms and point to the existence of a cluster of firms that have been managerially attentive to their real options. Such observed alertness can be viewed as an intangible learning resource contributing to decision-making and managerial options exercising, and therefore can be utilised to address issues of real options implementation in firms. This can be a first step towards integrating and reconciling empirical research on the determinants of investments and other studies on firm performance outcomes (see also Reuer and Tong 2007a).

[Insert Figure 1 here]

\section{Conclusions}

Overall, this paper has identified the dominant decision-making and performance themes of real options theory in the disciplines of strategy and international management, focusing on the organisational and performance implications of real options. Figure 1 provides a generic overview of the main streams reviewed in this survey. It also depicts the interactions among these streams, suggesting that streams inform each other conceptually but further efforts are required to develop a more integrated real options-based view of the firm. 
Although it is admitted that the real options approach presents valuable advantages in dealing with uncertainty and contributing to firms' evolutionary strategies, it does run into several practical and behavioural boundaries. Indeed, every firm assumes a fragile commitment-flexibility balance, which can be distorted towards distressful positions due to flawed real options thinking and complexity. Empirical evidence suggests that the real options logic sometimes constitutes part of managerial thinking and decision-making and can, to a moderate extent, be embedded in growth and the value of operating options. In fact, recent statistical findings reveal that real options attention, knowledge and management can be more crucial for organisations than real options opportunities. Hence the ability of decision-makers to explore and appraise real options prospects is a source of value for corporations. Only if managers acquire the flexibility capability to capitalise on upside potential, whilst mitigating downside risks, can the evolutionary competitive advantage of MNCs for example be revealed fully through real options. Future research in this area should examine theoretical and empirical aspects of real options attention in organisations and methods for real options diffusion and decision-making and these elements should consider the strategic, behavioural and operational facets of the organisation. Specifically, three key issues for future research emerge from the above thematic findings. Due to space constraints, other areas for further research and conceptual development matters will need to be discussed in a separate paper.

First, although several forms of real options decision-making can be identified in the literature, there is no theoretical or economic framework to explain the behavioural, rather than rational, implications of real options decision-making in firms. This addresses how decision-makers make informed real options decisions and concerns the cognitive factors triggering option-based attitudes towards investment structuring, resources management and managerial learning. Research related to the processes of real options decision-making and firms' heteregoneity in exploiting real options prospects should attempt to bridge further the gap between economic theory and management practice. Economic models of the organisation that go beyond the usual theory predictions can be developed to examine these important aspects, incorporate real options implementation issues in decision-making, and allow for deeper examinations of the exercising properties of real options in strategy and multinational operations. The influence of behavioural bias and flawed risk perceptions on managers' intuitive handling of real options can also be considered, but under more general framings of uncertainty. This would provide additional insights on the performance dynamics of real options in organisations and help integrate further the various streams identified.

Second, no explicit statistical study has directly examined the performance implications of real options skills, competences and decision-making in large firms in general, and MNCs in particular. Those investing in software and learning capabilities to apply real options analysis for project monitoring and operations are more inclined to validate Kogut's MNH, as well as real options theory's predictions of competitive advantage, than are firms unaware of their real options (Kogut 1984, 1985; Trigeorgis 1996). Indeed, recent evidence suggests that managerial capabilities and specific factors within firms contribute to real options value (Tong and Reuer 2006, 2007a; Ioulianou and Trigeorgis 2008). Existing research focuses on the impact of real options proxies (resources) on performance, but generally omits to incorporate real options knowledge and real options decision-making into the performance function (Reuer and Leiblein 
2000; Pantzalis 2001; Alonso et al. 2005). These gaps can be overcome by studying the determinants of competitive advantage in firms that have acquired knowledge for real options analysis, and perhaps developed skills or partial capabilities, and possibly by investigating the antecedents of such skills in organisations. This would be a step towards a uniform view of real options decision-making. The concept of real options attention is discussed in this review precisely to convey that real options planning is not a systematic managerial practice, but rather an intangible component of a company's resource base.

Third, as practitioners are willing seriously to acquire additional skills in the real options "technology" (Triantis and Borison 2001; Triantis 2005), this increased attention, as a prerequisite for real options decision-making, can be exploited to facilitate diffusion and investigate how this varies across firms and business units. This would help address a number of unresolved issues in the real option debate.

Acknowledgments

Thanks are due to Noel O'Sullivan and Allan Macpherson, the associate editor and the editor, and two anonymous reviewers for their insightful comments and suggestions on earlier versions of this work.

\section{References}

Aabo, T. \& Simkins, B. J. (2005). Interaction between real options and financial hedging: Fact or fiction in managerial decision-making. Review of Financial Economics, 14, pp. 353-369.

Adner, R. (2007). Real Options and Resource Reallocation Processes. Advances in Strategic Management, 24, pp. 363-372.

Adner, R. \& Levinthal, D. A. (2004a). What is not a real option: Considering boundaries for the application of real options to business strategy. Academy of Management Review, 29, pp. 74-85.

Adner, R. \& Levinthal, D. A. (2004b). Reply: real options and real tradeoffs. Academy of Management Review, 29, pp. 102-126.

Allen, L. \& Pantzalis, C. (1996). Valuation of the Operating Flexibility of Multinational Corporations. Journal of International Business Studies, 27, pp. 633-653.

Alonso, P.A., Palenzuela, V.A. \& Herrero, G.F. (2005). Real options as a component of the market value of stocks: evidence from the Spanish Stock Market. Applied Economics, 37, pp. 1673-1691.

Amram, M. \& Kulatilaka, N. (1997). Real Options: Managing Strategic Investment in an Uncertain World, Boston: Harvard Business School Press. 
Andersen, T. J. (2000). Real options analysis in strategic decision-making: an applied approach in a dual options framework. Journal of Applied Management Studies, 9, pp. 235-255.

Barnett, M. L. (2003). Falling off the fence? A realistic appraisal of a real options approach to corporate strategy. Journal of Management Inquiry, 12, pp. 185-196.

Barnett, M. L. (2005). Paying attention to real options. $R \& D$ Management, 35, pp. 6172.

Barnett, M. L. (2008). An Attention-Based View of Real Options Reasoning. Academy of Management Review, 33, pp. 606-628.

Barney, J. (1986). Strategic factor markets: Expectations, luck and business strategy. Management Science, 32, pp. 1231- 1241.

Belderbos, R. \& Zou, J. (2009). Real options and firm affiliate divestments: A portfolio perspective. Journal of International Business Studies, 40, pp. 600-620.

Block, S. (2007). Are real options actually used in the real world? The Engineering Economist, 52, pp. 255-267.

Bloom, N. \& Van Reenen, J. (2002). Patents, Real Options and Firm Performance. The Economic Journal, 112, pp. C97-C116.

Boisot, M. \& MacMillan, I. C. (2004). Crossing Epistemological Boundaries: Managerial and Entrepreneurial Approaches to Knowledge Management. Long Range Planning, 37, pp. 505-524.

Borissiouk, O. \& Peli, J. (2001). Real option approach to R\&D project valuation: Case study at Serono International S.A. Financier, 8, pp. 7-71.

Borisson, A. (2005). Real option analysis: where are the emperor's clothes? Journal of Applied Corporate Finance, 17, pp. 17-31.

Bowman, E. H. \& Hurry, D. (1993). Strategy through the options lens: An integrated view of resource investments and the incremental-choice process. Academy of Management Review, 18, pp. 760-782.

Bowman, E. H. \& Moskowitz, G. T. (2001). Real Options Analysis and Strategic Decision-making. Organization Science, 12, pp. 772-777.

Brouthers, K., Brouthers, L. \& Werner, S. (2008). Real Options, International Entry Mode Choice and Performance. The Journal of Management Studies, 45, pp. 937-960.

Brouthers, K. \& Dikova, D. (2010). Acquisitions and Real Options: The Greenfield Alternative. The Journal of Management Studies, 47, pp. 1048-1071.

Buckley, A. \& Tse, K. (1996). Real operating options and foreign direct investment: A synthetic approach. European Management Journal, 14, pp. 304-314. 
Buckley, P. J. \& Casson, M. C. (1998). Models of the multinational enterprise. Journal of International Business Studies, 29, pp. 21-44.

Bulan, L. T. (2005). Real options, irreversible investment and firm uncertainty: New evidence from U.S. firms. Review of Financial Economics, 14, pp. 255-279.

Burger-Helmchen, T. (2009). Options chain and change management: A structural equation applications. European Management Journal, 27, pp. 176-186.

Busby, J. S. \& Pitts, C. G. C. (1997). Real options in practice: an exploratory survey of how finance officers deal with flexibility in capital appraisal. Management Accounting Research, 8, pp. 169-186.

Campa, J. M. (1994). Multinational Investment Under Uncertainty in the Chemical Processing Industries. Journal of International Business Studies, 25, pp. 557-578.

Capel, J. (1997). A real options approach to economic exposure management. Journal of International Financial Management and Accounting, 8, pp. 87-113.

Carr, N. (2002). Unreal options. Harvard Business Review, 80, pp. 22.

Carter, D., Pantzalis, C. \& Simkins, B. (2003). Asymmetric exposure to foreign exchange risk: financial and real option hedges implemented by US multinational corporations. The 7th Annual Real Options Conference. McDonough School of Business, Georgetown University, Washington.

Chang, S. J. (1995). International Expansion Strategy of Japanese Firms: Capability Building through Sequential Entry. Academy of Management Journal, 38, pp. 383-407.

Chang, S. J. \& Rosenzweig, P. M. (1998). Industry and regional patterns in sequential foreign market entry. The Journal of Management Studies, 35, pp. 797-822.

Chang, S. J. \& Rosenzweig, P. M. (2001). The Choice of Entry Mode in Sequential Foreign Direct Investment. Strategic Management Journal, 22, pp. 747-776.

Chen, H., Hu, M.Y. \& Shieh, J.C. (1991). The Wealth Effect of International Jointventures: The Case of US Investment in China. Financial Management, 20, pp. 31-41.

Chi, T. (2000). Option to acquire or divest a joint-venture. Strategic Management Journal, 21, pp. 665-687.

Chi, T. \& Levitas, E. (2007). An Examination of Options Embedded in a Firm's Patents: The Value of Dispersion in Citations. Advances in Strategic Management, 24, pp. 405-427.

Chi, T. \& McGuire, D. J. (1996). Collaborative ventures and value of learning: Integrating the transaction cost and strategic option perspectives on the choice of market entry modes. Journal of International Business Studies, 27, pp. 285-307.

Chi, T. \& Seth, A. (2009). A Dynamic model of the choice of mode for exploiting complementary capabilities. Journal of International Business Studies, 40, pp. 365-387. 
Chung, C. C. \& Beamish, P. W. (2005). Investment mode strategy and expatriate strategy during times of economic crisis. Journal of International Management, 11, pp. 331-355.

Chung, C.C., Lee, S-H., Beamish, P.W. \& Isobe, T. (2010). Subsidiary expansion/contraction during times of economic crisis. Journal of International Business Studies, 41, pp. 500-516.

Chung, K. \& Charoenwong, C. (1991). Investment options, assets in place and the risk of stocks. Financial Management, 20, pp. 21-33.

Coff, R. \& Laverty, K. (2001). Real options of knowledge assets: Panacea or Pandora's box? Business Horizons, 44, pp. 73-79.

Coff, R. W. \& Laverty, K. J. (2007). Real Options Meet Organizational Theory: Coping with Path Dependencies, Agency Costs, and Organizational Form. Advances in Strategic Management, 24, pp. 333-361.

Colombo, M. G. (2003). Alliance form: A test of the contractual and competence perspectives. Strategic Management Journal, 24, pp. 1209-1229.

Cornelius, P., Van de Putte, A. \& Romani, M. (2004). Three Decades of Scenario Planning in Shell. California Management Review, 48, pp. 92-111.

Courchane, M., Nickerson, D. \& Sullivan, R. (2002). Investment in internet banking as a real option: theory and tests. Journal of Multinational Financial Management, 12, pp. 347-363.

Cuervo-Cazurra, A. \& Un, C. A. (2010). Why some firms never invest in formal R\&D. Strategic Management Journal, 31, pp. 759-779.

Cuypers, I. R. P. \& Martin, X. (2006). What makes and what does not make a real option? A study of international joint-ventures. Academy of Management Annual Meeting. Atlanta, Georgia.

Cuypers, I. R. P. \& Martin, X. (2010). What makes and what does not make a real option? A study of equity shares in international joint-ventures. Journal of International Business Studies, 41, pp. 47-69.

Dalziel, M. (2009). Foregoing the flexibility of real options: when and why firms commit to investment decisions. British Journal of Management, 20, pp. 401-412.

De Meza, D. \& Van Der Ploeg, F. (1987). Production Flexibility as a Motive for Multinationality. The Journal of Industrial Economics, 35, pp. 343-351.

De Neufville, R. (2003). Real Options: Dealing with Uncertainty in Systems Planning and Design. Integrated Assessment, 4, pp. 26-34.

De Treville, S. \& Trigeorgis, L. (2010). It May Be Cheaper to Manufacture at Home. Harvard Business Review, October, pp. 84-87. 
Denning, K. C., Hulburt, H. \& Ferris, S. P. (2006). Risk and wealth effects of U.S. firm joint-venture activity. Review of Financial Economics, 15, pp. 271-285.

Dhanani, A. (2004). The Management of Exchange-Rate Risk: A Case from the Manufacturing Industry. Thunderbird International Business Review, 46, pp. 317-338.

Dixit, A. K. \& Pindyck, R. S. (1994). Investment under Uncertainty, New Jersey: Princeton University Press.

Doukas, J. \& Travlos, N. G. (1988). The effect of corporate multinationalism on shareholders' wealth: Evidence from international acquisitions. Journal of Finance, 43, pp. 1161-1175.

Driouchi, T. \& Bennett, D. (2011). Real options in multinational decision making: Managerial awareness and risk implications. Journal of World Business, 46: in press.

Driver, C. \& Whelan, B. (2001). The effect of business risk on manufacturing investment: Sectoral survey evidence from Ireland. Journal of Economic Behavior and Organization, 44, pp. 403-412.

Estrada, I., de la Fuente, G. \& Martin-Cruz, N. (2010). Technology joint venture formation under the real options approach. Research Policy, 39, pp. 1185-1197.

Faulkner, T. (1996). Applying 'Options Thinking' to R\&D Valuation. Research Technology Management, May-June, pp. 50-56.

Fichman, R., Keil, M. \& Tiwana, A. (2005). Beyond Valuation: Options Thinking in IT Project Management. California Management Review, 47, pp. 74-100.

Fisch, J. H. (2008). Investment in new foreign subsidiaries under receding perception of uncertainty. Journal of International Business Studies, 39, pp. 370-386.

Fisch, J. H. (2011). Real call options to enlarge foreign subsidiaries - The moderating effect of irreversibility on the influence of economic volatility and political instability on subsequent FDI. Journal of World Business, forthcoming.

Folta, T. B. (1998). Governance and uncertainty: the trade-off between administrative control and commitment. Strategic Management Journal, 19, pp. 1007-1029.

Folta, T. B., Johnson, D. R. \& O'Brien, J. P. (2006). Uncertainty, irreversibility, and the likelihood of entry: An empirical assessment of the option to defer. Journal of Economic Behavior and Organization, 61, pp. 432-452.

Folta, T. B. \& Miller, K. D. (2002) Real options in equity partnerships. Strategic Management Journal, 23, pp. 77-88.

Folta, T. B. \& O'Brien, J. P. (2004). Entry in the presence of dueling options. Strategic Management Journal, 25, pp. 121-138.

Folta, T. B. \& O'Brien, J. P. (2007). Market versus Managerial Valuations of Real Options. Advances in Strategic Management, 24, pp. 199-224. 
Foss, N. J. (1998). The resource-based perspective: An assessment and diagnosis of problems. Scandinavian Journal of Management, 14, pp. 133-149.

Garud, R., Kumaraswamy, A. \& Nayyar, P. (1998). Real options or Fool's Gold?: Perspective Makes the Difference. Academy of Management Review, 23, pp. 213-217.

Graham, J. R. \& Harvey, C. R. (2001). The theory and practice of corporate finance: evidence from the field. Journal of Financial Economics, 60, pp. 187-243.

Gulamhussen, M.A. (2009). A Theoretical perspective on the location of banking FDI. Management International Review, 49, pp. 163-178.

Guler, I. (2007). An Empirical Examination of Management of Real Options in the U.S. Venture Capital Industry. Advances in Strategic Management, 24, pp. 485-506.

Harris, D., Morck, R., Slemrod, J. \& Yeung, B. (1993). Income Shifting in US Multinational Corporations In Giovannini, A., Hubbard, R.G. \& Slemrod, J. (Eds.) Studies in International Taxation. NBER and University of Chicago Press.

Hartmann, M. \& Hassan, A. (2006). Application of real options analysis for pharmaceutical R\&D project valuation: empirical results from a survey. Research Policy, 35, pp. 343-354.

Helfat, C. E. \& Raubitschek, R. S. (2000). Product sequencing: Co-evolution of knowledge, capabilities and products. Strategic Management Journal, 21, pp. 961-979.

Howell, S.D. \& Jagle, A.J. (1997). Laboratory Evidence on how Managers Value Real Growth Options. Journal of Business Finance and Accounting, 24, pp. 915-935.

Hurry, D., Miller, A. T. \& Bowman, E. H. (1992). Calls on high technology: Japanese exploration of venture capital investments in the United States. Strategic Management Journal, 13, pp. 85-101.

Janney, J. \& Dess, G. (2004). Can Real Options Analysis Improve Decision-Making? Promises and Pitfalls. Academy of Management Executive, 18, pp. 60-75.

Jiang, M., Aulakh, P. \& Pan, Y. (2009). Licensing duration in foreign markets: A real options perspective. Journal of International Business Studies, 40, pp. 559-577.

Kemna, A. G. Z. (1993). Case studies on real options. Financial Management, 22, pp. 259-270.

Kester, W. C. (1984). Today's Options for Tomorrow's Growth. Harvard Business Review, 62, pp. 153-160.

Kim, D. \& Kogut, B. (1996). Technological platforms and diversification. Organisation Science, 7, pp. 283-301.

Kogut, B. (1984). Normative Observations on the International Value-Added Chain and Strategic Groups. Journal of International Business Studies, 15, pp. 151-167. 
Kogut, B. (1985). Designing Global Strategies: Profiting from Operational Flexibility. Sloan Management Review, 27, pp. 27-38.

Kogut, B. (1989). A note on global strategies. Strategic Management Journal, 10, pp. 383-389.

Kogut, B. (1991). Joint-ventures and the Option to Expand and Acquire. Management Science, 37, pp. 19-33.

Kogut, B. \& Chang, S.J. (1996). Platform investments and volatile exchange rates: Direct investment in the US by Japanese electronic companies. Review of Economics and Statistics, 78, pp. 221-231.

Kogut, B. \& Kulatilaka, N. (1994a). Operating flexibility, global manufacturing, and the option value of a multinational network. Management Science, 40, pp. 123-139.

Kogut, B. \& Kulatilaka, N. (1994b). Options Thinking and Platform Investments: Investing in Opportunity. California Management Review, 36, pp. 52-71.

Kogut, B. \& Kulatilaka, N. (2001). Capabilities as Real Options. Organization Science, 12, pp. 744-758.

Kogut, B. \& Kulatilaka, N. (2004). Real Options Pricing and Organizations: The Contingent Risks of Extended Theoretical Domains. Academy of Management Review, 29, pp. 102-110.

Kouvelis, P., Axarloglou, K. \& Sinha, V. (2001). Exchange rates and the choice of ownership structure of production facilities. Management Science, 47, pp. 1063-1080.

Krychowski, C. \& Quelin, B. (2010). Real Options and Strategic Investment Decisions: Can They Be of Use to Scholars? The Academy of Management Perspectives, 24, pp. 65-78.

Kumar, M. V. S. (2005). The value from acquiring and divesting a joint-venture: A real options approach. Strategic Management Journal, 25, pp. 321-331.

Kyläkeiko, K., Sandström, J. \& Virkkunen, V. (2002). Dynamic capability view in terms of real options. International Journal of Production Economics, 80, pp. 65-83.

Lee, S-H., Peng, M. \& Barney, J. (2007). Bankruptcy Law and Entrepreneurship Development: A Real Options Perspective. Academy of Management Review, 32, pp. 257-272.

Lee, S-H., Makhija, M. \& Paik, Y. (2008). The value of real options investments under abnormal uncertainty: The case of the Korean economic crisis. Journal of World Business, 43, pp. 16-34.

Lee, S-H. \& Makhija, M. (2009a). The effect of domestic uncertainty on the real options value of international investments. Journal of International Business Studies, 40, pp. 405-420. 
Lee, S-H. \& Makhija, M. (2009b). Flexibility in internationalisation: Is it valuable during an economic crisis?. Strategic Management Journal, 30, pp. 537-555.

Leiblein, M. J. (2003). The Choice of Organizational Governance Form and Performance: Predictions from Transaction Cost, Resource-based, and Real Options Theories. Journal of Management, 29, pp. 937-961.

Leiblein, M. J. \& Miller, D. J. (2003). An empirical examination of transaction and firm-level influences on the vertical boundaries of the firm. Strategic Management Journal, 24, pp. 839-859.

Li, J. (2007a). Real options theory and international strategy: A critical review. Advances in Strategic Management, 24, pp. 67-101.

Li, J. \& Rugman, A. (2007). Real options and the theory of foreign direct investment. International Business Review, 16, pp. 687-712.

Li, J. \& Li, Y. (2010). Flexibility versus commitment: MNEs' ownership strategy in China. Journal of International Business Studies, 41, pp. 1550-1571.

Li, L. (2007b). Multinationality and Performance: A synthetic review and research agenda. International Journal of Management Reviews, 9, pp. 117-139.

Li, Y. (2008). Duration analysis of venture capital staged financing: A real options perspective. Journal of Business Venturing, 23, pp. 497-512.

Lint, O. \& Pennings, E. (1998). R\&D as an option on market introduction. $R \& D$ Management, 4, pp. 279-287.

Lint, O. \& Pennings, E. (2001). An option approach to the new product development process: A case study at Philips Electronics. R\&D Management, 31, pp. 163-172.

Luehrman, T. A. (1998a). Strategy as a portfolio of real options. Harvard Business Review, September-October, pp. 89-99.

Luehrman, T. A. (1998b). Investment opportunities as real options. Harvard Business Review, July-August, pp. 51-67.

Markman, G., Gianiodis, P. \& Phan, P. (2009). Supply-side innovation and technology commercialisation. The Journal of Management Studies, 46, pp. 625-649.

Mascarenhas, B. (1982). Coping with Uncertainty in International Business. Journal of International Business Studies, 13, pp. 87-98.

McCarthy, D.J. \& Puffer, S.M. (1997). Strategic investment flexibility for MNE success in Russia: Evolving beyond entry modes. Journal of World Business, 32, pp. 293-319.

McGrath, R. G. (1997). A real options logic for initiating technology positioning investments. Academy of Management Review, 22, pp. 974-996. 
McGrath, R. G. (1998). Only Fools Rush In? Using Real Options Reasoning to Inform the Theory of Technology Strategy: Response to Garud, Kumaraswamy, and Nayyar. Academy of Management Review, 23, pp. 214-216.

McGrath, R. G. (1999) Falling Forward: Real Options Reasoning and Entrepreneurial Failure. Academy of Management Review, 24, pp. 13-30.

McGrath, R. G., Ferrier, W. J. \& Mendelow, A. L. (2004). Response: real options as engines of choice and heterogeneity. Academy of Management Review, 29, pp. 86-101.

McGrath, R. G. \& MacMillan, I. C. (2000). Assessing technology projects using real options reasoning. Research Technology Management, 43, pp. 35-49.

McGrath, R. G. \& Nerkar, A. (2004). Real Options Reasoning and a New Look at the R\&D Investment Strategies of Pharmaceutical Firms. Strategic Management Journal, 25, pp. 1-21.

Mello, A. S., Parsons, J. E. \& Triantis, A. J. (1995). An Integrated Model of Multinational Flexibility and Financial Hedging. Journal of International Economics, 39 , pp. 27-51.

Miller, K. D. (2002). Knowledge Inventories and Managerial Myopia. Strategic Management Journal, 23, pp. 689-706.

Miller, K. D. \& Arikan, A. (2004). Technology search investments: Evolutionary, option reasoning, and option pricing approaches. Strategic Management Journal, 25, pp. 473-485.

Miller, K. D. \& Folta, T. B. (2002). Option value and entry timing. Strategic Management Journal, 23, pp. 655-665.

Miller, K. D. \& Reuer, J. J. (1998a). Firm Strategy and Economic Exposure to Foreign Exchange Rate Movements. Journal of International Business Studies, 29, pp. 493-513.

Miller, K. D. \& Reuer, J. J. (1998b). Research notes and communications: Asymmetric corporate exposures to foreign exchange rate changes. Strategic Management Journal, 19, pp. 1183-1191.

Miller, K. D. \& Shapira, Z. (2004). An Empirical Test of Heuristics and Biases Affecting Real Option Valuation. Strategic Management Journal, 25, pp. 269-284.

Miller, K. D. \& Waller, H. G. (2003). Scenarios, real options and integrated risk management. Long Range Planning, 36, pp. 93-107.

Miller, L. T. \& Park, C. S. (2004). Economic analysis in the maintenance, repair, and overhaul industry: An options approach. The Engineering Economist, 49, pp. 21-41.

Mol, M., Van Tulder, R., \& Beije, P. (2005). Antecedents and performance consequences of international outsourcing. International Business Review, 14, pp. 599617. 
Mun, J. (2002). Real Options Analysis: Tools and Techniques for Valuing Strategic Investments and Decisions, Hoboken, New Jersey: John Wiley \& Sons, Inc.

Mun, J. (2003). The Real Options Analysis Course: Business Cases and Software Applications, Hoboken, New Jersey: John Wiley \& Sons, Inc.

Muralidhar, A. (1992). Volatility, Flexibility and the Multinational Enterprise. PhD Thesis, MIT Sloan School of Management.

Nanda, A. \& Williamson, P. J. (1995). Use Joint-ventures to ease the pain of restructuring. Harvard Business Review, 73, pp. 119-129.

Newton, D., Paxson, D. \& Widdinks, M. (2004). Real R\&D options. International Journal of Management Reviews, 5-6, pp. 113-130.

Nichols, N. A. (1994). Scientific Management at Merck: An Interview with CFO Judy Lewent. Harvard Business Review, 72, pp. 89-99.

O'Brien, J. \& Folta, T. (2009). Sunk costs, uncertainty and market exit: A real options perspective. Industrial and Corporate Change, 18, pp. 807-833.

Oriani, R. (2007). Technology Switch Option and the Market Value of the Firm: A Model and an Empirical test. Advances in Strategic Management, 24, pp. 429-458.

Oriani, R. \& Sobrero, M. (2008). Uncertainty and the market valuation of R\&D within a real options logic. Strategic Management Journal, 29, pp. 343-361.

Paddock, J., Siegel, D. \& Smith, J. (1988). Option valuation and claims on physical assets: The case of offshore petroleum leases. Quarterly Journal of Economics, 103, pp. 479-508.

Pandza, K., Horsburgh, S. \& Andrej, K. G. (2003). A real options approach to managing resources and capabilities. International Journal of Operations \& Production Management, 23, pp. 1010-1032.

Pantzalis, C. (2001). Does Location Matter? An Empirical Analysis of Geographic Scope and MNC Market Valuation. Journal of International Business Studies, 32, pp. 133-155.

Pennings, E. \& Lint, O. (1997). The option value of advanced R\&D. European Journal of Operational Research, 103, pp. 83-94.

Petersen, B., Welch, D. E. \& Welch, L. S. (2001). Creating Meaningful Switching Options in International Operations. Long Range Planning, 33, pp. 688-705.

Philippe, H. (2005). Corporate Governance: A New Limit to Real Options Valuation? Journal of Management and Governance, 9, pp. 129-149.

Porter, M. E. (1990). The Competitive Advantage of Nations, London: McMillan. 
Power, B. \& Reid, G.C. (2006). A Test of Real Options Logic by Entrepreneurs. The 10th Annual Real Options Conference. Columbia Business School, University of Columbia, New York.

Quigg, L. (1993). Empirical testing of real option-pricing models. Journal of Finance, 58, pp. 621-640.

Ramezani, C. A., Soenen, L. \& Jung, A. (2002). Growth, Corporate Profitability, and Value Creation. Financial Analysts Journal, December-November, pp. 56-67.

Rangan, S. (1998). Do Multinationals Operate Flexibly? Theory and Evidence. Journal of International Business Studies, 29, pp. 217-237.

Raynor, M. (2002). Diversification as real options and the Implications of firm-specific risk and performance. The Engineering Economist, 47, pp. 371-389.

Raynor, M. \& Leroux, X. (2004). Strategic flexibility in R\&D. Research Technology Management, 47, pp. 27-32.

Reuer, J. J. \& Leiblein, M. J. (2000). Downside Risk Implications of Multinationality and International Joint-ventures. Academy of Management Journal, 43, pp. 203-214.

Reuer, J. J. \& Tong, T. W. (2007b). Corporate investments and growth options. Managerial and Decision Economics, 28, pp. 863-877.

Reuer, J. J. \& Tong, T. W. (2007a). How Do Real Options Matter? Empirical Research on Strategic Investments and Firm Performance. Advances in Strategic Management, 24, pp. 145-173.

Reuer, J. J. \& Tong, T. W. (2010). Discovering valuable growth opportunities: An analysis of equity alliances with IPO firms. Organisation Science, 21, pp. 202-215.

Rivoli, P. \& Salorio, E. (1996). Foreign direct investment and investment under uncertainty. Journal of International Business Studies, 27, pp. 335-357.

Rugman, A. M. \& Li, J. (2005). Real Options and International Investments, Cheltenham: Elgar.

Ryan, P. A. \& Ryan, G. P. (2002). Capital Budgeting Practices of the Fortune 1000: How Have Things Changed? Journal of Business and Management, 8, pp. 355-364.

Sanchez, R. (1995). Strategic flexibility in product competition. Strategic Management Journal, 16, pp. 135-159.

Sanchez, R. (2003). Integrating transaction costs theory and real options theory. Managerial and Decision Economics, 24, pp. 267-282.

Santoro, M. \& McGill, J. (2005). The effect of uncertainty and asset co-specialisation on governance in biotechnology alliances. Strategic Management Journal, 26, pp. 1261-1269. 
Scherpereel, C. (2008). The option-creating institution: A real options perspective on economic organisation. Strategic Management Journal, 29, pp. 455-470.

Schwartz, E. S. \& Trigeorgis, L. (2001). Real options and investment under uncertainty, Cambridge, MA: MIT Press.

Smit, H. T. J. \& Trigeorgis, L. (2004). Real Options and Games, New Jersey: Princeton University Press.

Smit, H. T. J. \& Trigeorgis, L. (2007). Strategic Options and Games in Analysing Dynamic Technology Investments, Long Range Planning, 40, pp. 84-114.

Smit, H.T. \& Moraitis, T. (2010). Serial acquisition options. Long Range Planning, 43, pp. 85-103.

Teece, D. J., Pisano, G. \& Shuen, A. (1997). Dynamic capabilities and strategic management. Strategic Management Journal, 18, pp. 509-533.

Tiwana, A., Wang, J., Keil, M. \& Ahluwalia, P. (2007). The bounded rationality bias in managerial valuation of real options: theory and evidence from IT projects. Decision Sciences Journal, 38, pp. 157-181.

Tong, T. W. \& Reuer, J. (2006). Firm and Industry Influences on the Value of Growth Options. Strategic Organization, 4, pp. 71-96.

Tong, T. W. \& Reuer, J. J. (2005). Real Options in International Joint-ventures. Journal of Management, 31, pp. 403-423.

Tong, T. W. \& Reuer, J. J. (2007a). Real options in multinational corporations: organizational challenges and risk implications. Journal of International Business Studies, 38, pp. 215-230.

Tong, T. W. \& Reuer, J. J. (2007b). Real Options in Strategic Management. Advances in Strategic Management, 24, pp. 3-28.

Tong, T. W., Reuer, J. J. \& Peng, M. W. (2008a). International Joint-ventures and the Value of Growth Options. Academy of Management Journal, 51, pp. 1014-1029.

Tong, T.W., Alessandri, T.M., Reuer, J.J. \& Chintakananda, A. (2008b). How much does country matter? An analysis of firms' growth options. Journal of International Business Studies, 39, pp. 387-405.

Triantis, A. \& Borison, A. (2001). Real Options: State of the Practice. Journal of Applied Corporate Finance, 14, pp. 8-24.

Triantis, A. (2005). Realizing the Potential of Real Options: Does Theory Meet Practice? Journal of Applied Corporate Finance, 17, pp. 8-16.

Trigeorgis, L. (1996). Real Options: Managerial Flexibility and Strategy in Resource Allocation, London: MIT Press. 
Trigeorgis, L. (1999). Real Options and Business Strategy: Applications to decision making, London: Risk Books.

Trigeorgis, L. (2005). Making of Real Options Simple: An Overview and Applications in Flexible/Modular Decision-Making. The Engineering Economist, 50, pp. 25-53.

Trigeorgis, L. \& Ioulianou. S. (2008). Impact of Growth Options, Real Options Capability and

Multinationality on Firm Performance and Stock Returns. The 15th Annual Conference of the Multinational Finance Society. Rutgers University, New Jersey.

Tserlukevich, Y. (2008). Can real options explain financing behaviour?. Journal of Financial Economics, 89, pp. 232-252.

Vassolo, R. S., Anand, J. \& Folta, T. B. (2004). Non-additivity in portfolios of exploration activities: A real options-based analysis of equity alliances in biotechnology. Strategic Management Journal, 25, pp. 1045-1061.

Verbeeten, F.M. (2006). Do organisations adopt sophisticated capital budgeting practices to deal with uncertainty in the investment decision? A research note. Management Accounting Research, 17, pp. 106-120.

Villalonga, B. \& McGahan, A. (2005) The Choice among Acquisitions, Alliances and Divestitures. Strategic Management Journal, 26, pp. 1183-1208.

Xu, D., Zhou, C. \& Phan, P. (2009). A real options perspective on sequential acquisitions in China. Journal of International Business Studies, 41, pp. 166-174.

Wang, Y. \& Miao, J. (2006). Using Strategic Alliances to Make Decisions about Investing in Technological Innovations. Journal of International Management, 23, pp. 195-201.

Wernerfelt, B. (1984). A Resource-based view of the Firm. Strategic Management Journal, 5, pp. 171-180.

Zardkoohi, A. (2004). Do real options lead to escalation of commitment. Academy of Management Review, 29, pp. 111-119 